\title{
Looking Outward: The Symbiotic Relationship Between Your Media Students and The Community of Which They are A Part
}

\author{
By Linda Bartrom-Olsen
}

$\triangle$ television production class generally and naturally focuses for subject matter inward, upon its own members, their own activities, or perhaps a bit beyond, upon their own school organizations, courses, sports and individuals. While this "close to home" focus enlarges the experience of the class with regard to what a news organization does, the topics are limited and after awhile become repetitious. There is also a little too much of the element of "safety reporting" on things they know about and feel completely comfortable with. The comfort may be physical comfort in an environment the students are used to, or socially comfortable with people and faces they have seen and spoken with before. Help your learners turn their focus outward. Venturing out into that "Brave New World" beyond the horizon of the schoolyard is what they need to do once in awhile, forcing your young cast and crew to move beyond their "comfort zone".

However, the world comes with its own set of drawbacks and sometimes even outright dangers. Strangers are not always friendly, circumstances are not always safe, and events that can be reported on, may incorporate at least partially, components that students' parents may not want them to be a part of at all. So is reporting on events beyond the schoolyard, beyond that everyday margin of safety even advisable? And the answer is... absolutely yes!
This is because there is an extended family of every learner: the extended family of social occasions. This includes local church, community and governmental events, which provide a nearly endless pool of reportable, filmable, and safe topics for your TV production students to archive for the future through their programming. This type of reporting will not of course, be the only type of reporting your class does, nor does it even have to be frequent. But

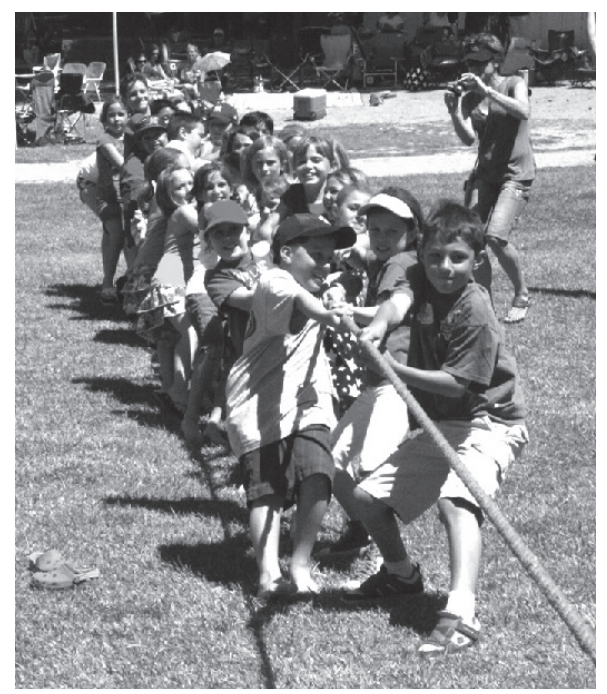

Figure 1. The vp picnic covered by my students shows the kind of "beyond the schoolyard" events that are perfect for young reporters (photo by Robby Julian).

it should be regular, there should be a rhythm of internal reporting for practice, coupled with the occasional outreach into more unfamiliar territory of "Life-at-Large".

Several concrete examples of what my media students regularly film ex- ternal to school may provide some direction. Let's start with reaching into the various religions of your class for an on-the-spot report once a month. This has so many benefits educationally and socially, and our reports are reshown by the social studies teachers. These also make great Senior Projects or special reports for politcal science classes. Next, community events should be considered, like the Villa Park Memorial Day Picnic which we just filmed. These events find a great fan-club base and catapult your students into roles of importance as they memorialize events. Governmental meetings can also be taped and often a formal role as interns or the actual cameramen can be assumed by your students. Mine film the monthly Villa Park City Council Meetings and then import, put it on a DVD and submit for playback at our local station. The level of involvement will vary with the experience of your learners and the history of your class, but inroads into volunteerism regarding city events is easier than you might imagine.

In conclusion, you owe your students experience beyond your campus, but you also have a huge responsibility for watch-dogging what, where and when they choose to work. Help your learners develop a sense of the symbiotic relationship between reporters and the society of which they are a part. The sense of service which will result will not only serves their community, it will inevitably, and always, serve them as well. 